\title{
Development of a New Environmentally-Friendly Technology for Transportation of Mined Rock in the Opencast Mining
}

\author{
Sergey KUZMIN ${ }^{1}$, Olga KADNIKOVA ${ }^{2 *}$, Gulnara ALTYNBAYEVA ${ }^{3}$, \\ Andrey TURBIT ${ }^{4}$, Zauresh KHABDULLINA ${ }^{5}$ \\ ${ }^{1-5}$ Rudny Industrial Institute, 50 let Oktyabrya street 38, Rudny, 111500, Republic of Kazakhstan
}

\begin{abstract}
This article proposes a new technology of container carriage of rocks without construction of transport communications in an open-pit mine and with technological and energy-saving advantages. These advantages are: simultaneous excavation of rocks, transportation of rocks by the shortest distance, small mass of a container and mobility of a complex of hoists which will reduce energy expenses and the cost of transportation of the mined rock. One of the principal advantages of the developed technology is the decrease in environmental emissions into the atmosphere of the open-pit mine thanks to the reduction of the vehicle fleet. This technology will enable significant improvement of the environmental situation in the area of mining operations.
\end{abstract}

Keywords - Aerology; container technology; deep open-pit mine; hoist; open-pit mine; opencast mining; productivity; reduction of emissions.

\section{INTRODUCTION}

In the modern conditions, a need for efficient and environmentally safe development and management of subsurface resources is becoming ever more relevant. As a result of the scientific and technological revolution the adverse effect on the environment has significantly increased. The opencast mining, one of the principal sources of the environment pollution, plays the leading role in this area [1], [2].

In terms of power, conveyance of the mined rock along the edge of the open-pit mine by motor transport increases the rate of fuel consumption by 2-3 times [3]. Accordingly, the amount of harmful emissions into the atmosphere of the open-pit mine increases as well. Significant costs of conveying the rocks by motor transport limit the cost-efficient height of mine dumps, which leads to the increase of their occupied area and additional environmental losses.

The environmental issues caused by the use of motor transport at open-pit mines have several directions [4], [5]:

- Firstly, pollution of the atmosphere of the open-pit mines as a result of diesel engine emissions. It was found that the biggest rate of fuel consumption takes place during conveyance of the mined rock from the open-pit mines. Excavating-motor transport hubs have one fundamental disadvantage in the form of additional inefficient diesel fuel consumption during the down time in the process of loading a dump truck;

* Corresponding author.

E-mail address: kadnikovaolga@mail.ru 
- Secondly, dust emission in the process of blow-off from the surface of the mined rock in the truck body and from the wheel-road surface interaction. The high level of the dust blow-off from the dump truck surface results from a significant area of the rock surface, which is related to the geometric parameters of the truck body. During the interaction of the wheels with the road surface the level of dust emission depends on the speed of dump trucks and road surface. Additional road irrigation and surface improvement costs are required in order to fight dust emission;

- Thirdly, dust emission from the surface of external mine dumps of waste rock. As mentioned above, the external motor dumping sites are characterized by a large area of dump operations and a long-term running order. This results in a high level of dust blow-off from the surface of mine dumps and environmental damage for the surrounding land;

- Fourthly, the increase of the land area of external mine dumps and withdrawal of these areas from agriculture for long terms. The area of external mine dumps depends on their height, which in turn is determined by the cost-efficient height of rock hoisting by motor transport. High unit cost of motor transportation limits the height of mine dumps (usually up to 20-40 metres) and increases its area.

Delivery of mined rock to mine dumps or bunkers of concentrating factories accounts for the principal share of energy consumption in mining. The issue of transport support of the bottom levels of deep open-pit mines has no ultimate technological solution, while the principal share of transport costs falls on the cycle of hoisting the mined rock.

Enterprises developing deposits in the unconsolidated and water-flooded rock face significant transportation problems. A low load bearing capacity of rock, complicated road conditions lead to the fact that the prime cost of transportation works is double compared to the average values in other open-pit mines. Given the combination of the identified rock and technological issues in the conditions of critically increased man-caused pressure on the environment and intense competition in the external market, creation of an energy-saving and environmentally safe technology of opencast mining becomes very relevant.

Selection of technological equipment of open-pit mines is the most complicated issue in the technology of the existing open-pit mines. This shows that they have a range of contradictions requiring new solutions. With the lowering of mining in open-pit mines the distance of motor transportation increases therefore higher capacity dump trucks are required. Increase of the capacity of dump trucks disrupts the optimal ratio of the capacity of a shovel size of a face shovel to the dump truck's body capacity. In order to decrease the down time of expensive dump trucks it is required to increase the shovel power and standard dimensions of a face shovel. The increased dimensions of dump trucks require the extension of highways, manoeuvring platforms, etc., which significantly decreases the volumes of ore mining [6]. This facilitates increase in a number of internal open-pit mine loading points used in combined transportation.

\section{Methodology}

\subsection{Analysis of Existing Technologies}

In deep open-pit mines with combined motor-railway transport with the increase of depth of an open-pit mine the speed of construction of railway communications and loading warehouses gradually decreases due to narrowing of the working area, lagging behind of the outrunning overburden removal for formation of areas of a permanent open-pit mine edge 
slows down. Such platforms are necessary for positioning of stationary railway communications. Lagging behind of the overburden removal in the railway transport working area occurs due to a lower possible intensity of mining due to a long length of the working area of one excavator on the railway transport. Different speed of mining lowering on the motor and railway transport also contributes to the increasing separation of the motor transport's borders of the bottom level of the open-pit mine from the reloading warehouses located at the bottom working border of the railway transport.

The result of the abovementioned situation is a quality transition of the motor transport from the category of the link having the main advantage in its mobility to the category of the lifting link of the transport system under conditions, in which the worst properties of motor transport deteriorate - a high rate of fuel consumption and a very negative impact on the atmosphere of the open-pit mine. According to practical data the rate of fuel consumption of a dump truck during elevation doubles, which is related to a high capacity coefficient and low efficiency of any combustion engine. The unit cost of mining grows, the frequency of stoppage of an open-pit mine for aeration increases or a necessity to use individual protection means of personnel from irrespirable gas arises.

The principal deficiencies inherent in traditional technologies with motor, railway and combined motor and railway transport are as follows: a high coefficient of dead load of the truck body of vehicles; a small grade of transport communications in an open-pit mine; decline in the productivity of excavators, motor-excavating and railway hubs due to insufficient supply of excavators with the required amount of vehicles for reducing the down time of expensive equipment; a need for additional energy-intensive excavations in the process of reloading of the mined rock at the internal open-pit mine warehouses with combined transport; a high level of dust emission in the process of reloading of the mined rock at warehouses, during transportation and warehousing; increased height of rock hoisting at the external mine dumps and a need for additional equipment for downthrow (a bulldozer, a mined rock excavator); increase of the current coefficient of overburden removal due to deviation from the best possible way of formation of the intermediate side of the open-pit mine in the process of positioning of transport communications and reloading warehouses on temporary support in the working area of the open-pit mine; impossibility of automation of the transportation process of mined rock hoisting from the open-pit mine.

We shall determine concentration of harm in the open-pit mine in a traditional technology of mined rock transportation by motor transport [7].

The air volume airing the open-pit mine under the recirculating scheme $Q_{\mathrm{w}}, \mathrm{m}^{3} / \mathrm{s}$ is calculated according the equitation:

$$
Q=K \cdot h_{\mathrm{c}} \cdot U_{\mathrm{w}} \cdot L
$$

where

$K$ Coefficient of slowing down of air flow at the transition to the upper edge of the leeside, $K=0.9[8]$;

$L \quad$ Size of the open-pit mine surface towards the normal wind direction;

$h_{\mathrm{c}} \quad$ Thickness of free air flow above the upper edge of the leeside of the open-pit mine, m;

$U_{\mathrm{w}} \quad$ Speed of wind, $\mathrm{m} / \mathrm{s}$. 


$$
h_{\mathrm{c}}=H\left[\frac{4.6}{(\alpha-20)^{2}+20}+0.046\right] \text {, }
$$

where

$H \quad$ Depth of an open-pit mine, $100 \mathrm{~m}$;

$\alpha \quad$ Angle of slope of the leeside of the open-pit mine, $\operatorname{deg} \alpha=35^{\circ}$ [9].

The principal sources of dust and gas liberation in the open-pit mine are the following: drilling rigs, extraction-and-loading equipment, combustion engines, motorways.

Intensity of dust and gas liberation $\mathrm{J}, \mathrm{mg} / \mathrm{s}$ is determined according to the equitation:

$$
J=K_{\mathrm{u}} \cdot K_{\mathrm{s}} \cdot\left(1-K_{\mathrm{ef}}\right) \cdot F_{\mathrm{i}} \cdot P_{\mathrm{i}} \cdot m
$$

where

$K_{\mathrm{u}} \quad$ Coefficient of unaccounted sources, $K_{\mathrm{u}}=1.1[10]$;

$K_{\mathrm{s}} \quad$ Seasonal coefficient, for warm season $K_{\mathrm{s}}=1$ [10];

$K_{\text {ef }}$ Coefficient of efficiency of dust and gas suppression per types of equipment: excavators, bulldozers, drilling rigs $=0.6$; motor vehicles $=0.8$; for motor transport gases $K_{\text {ef }}=0.5[11]$;

$F_{\mathrm{i}} \quad$ Intensity of liberation of dust and gas in the process of work of one source, $\mathrm{mg} / \mathrm{s}$;

$P_{\mathrm{i}} \quad$ Coefficient of simultaneity of work of mechanisms of one type for drilling rigs and bulldozers equals to $=0.4$; for shovel excavators $=0.6$; for motor vehicles $=0.2[12]$. $J=1.1 \cdot 1 \cdot(1-0.6) \cdot 2600 \cdot 0.4 \cdot 1=458 \mathrm{mg} / \mathrm{s}$.

The results of calculation for other types of equipment are provided in Table 1.

TABle 1. Results of CALCUlation FOR Dust in AN OPEN-Pit Mine

\begin{tabular}{llll}
\hline Type of equipment & $\boldsymbol{m}_{\mathbf{i}}, \mathbf{p c s}$. & $\boldsymbol{F}_{\mathbf{i}}, \mathbf{m g} / \mathbf{s}$ & $\boldsymbol{J}, \mathbf{m g} / \mathbf{s}$ \\
\hline Drilling rigs & 1 & 2600 & 458 \\
Excavators & 2 & 400 & 211 \\
Dump trucks & 12 & 12000 & 6336 \\
Bulldozers & 1 & 2000 & 352 \\
\hline
\end{tabular}

A similar calculation is provided for gas. The results are presented in Table 2.

\begin{tabular}{|c|c|c|c|c|c|c|}
\hline Gas & $\begin{array}{l}\text { MAC } \\
\text { norm, \% }\end{array}$ & $\begin{array}{l}\text { Type of } \\
\text { equipment }\end{array}$ & $m_{\mathrm{i}}$, pcs. & $F_{\mathrm{i}}, \mathrm{mg} / \mathrm{s}$ & $J, \mathrm{mg} / \mathrm{s}$ & $\Sigma$ \\
\hline \multirow{2}{*}{ CO } & \multirow{2}{*}{20} & Dump trucks & 12 & 1150 & 60 & \multirow{2}{*}{236} \\
\hline & & Bulldozers & 1 & 1000 & 176 & \\
\hline \multirow{2}{*}{$\mathrm{N}_{2} \mathrm{O}_{5}$} & \multirow{2}{*}{5} & Dump trucks & 12 & 1305 & 70 & \multirow{2}{*}{264} \\
\hline & & Bulldozers & 1 & 1100 & 194 & \\
\hline \multirow{2}{*}{ Acrolein } & \multirow{2}{*}{0.7} & Dump trucks & 12 & 6 & 0.312 & \multirow{2}{*}{1.19} \\
\hline & & Bulldozers & 1 & 5 & 0.88 & \\
\hline
\end{tabular}

TABle 2. Results of CALCUlation FOR GAS IN AN OPEN-Pit Mine

$$
h_{\mathrm{c}}=100\left[\frac{4.6}{(35-20)^{2}+20}+0.046\right]=6.5 \mathrm{~m} \text {, }
$$




$$
Q=0.9 \cdot 6.5 \cdot 4.4 \cdot 480=12360 \mathrm{~m}^{3} / \mathrm{s} \text {. }
$$

The initial dust concentration in the atmosphere of an open-pit mine $\left(C, \mathrm{mg} / \mathrm{m}^{3}\right)$ is determined according to the equation:

$$
C=\frac{\sum J}{Q \cdot K_{\mathrm{r}}},
$$

where $K_{\mathrm{r}}$ is a coefficient considering reduction of concentration of dust and gas in the upper atmosphere, $K_{\mathrm{r}}=0.5-0.8[10]$.

$$
C=\frac{7357}{12360 \cdot 0.8}=0.74 \mathrm{mg} / \mathrm{m}^{3} .
$$

The initial dust concentration does not exceed MAC norms.

The initial concentration of $\mathrm{CO}$ gas:

$$
C=\frac{236}{12360 \cdot 0.8}=0.023 \mathrm{mg} / \mathrm{m}^{3} \text {. }
$$

The initial concentration of $\mathrm{N}_{2} \mathrm{O}_{5}$ gas:

$$
C=\frac{264}{12360 \cdot 0.8}=0.026 \mathrm{mg} / \mathrm{m}^{3} \text {. }
$$

The initial concentration of acrolein gas:

$$
C=\frac{1.19}{12360 \cdot 0.8}=0.0001 \mathrm{mg} / \mathrm{m}^{3} \text {. }
$$

In the period of absence of wind activity, the concertation of harm starts growing rapidly and leads to a forced down time of equipment of a mining enterprise.

Thus, the principal problem of deep open-pit mines is a transport problem. Current trends of development of traditional transportation technologies lead to reducing of the ore reserves, increasing of costs per $1000 \mathrm{~km}$ of transportation by road, increase of the atmosphere pollution and reduction of productive capacities of an open-pit mine. With the aim to increase efficiency new technologies of opencast mining are being developed [13]-[18] and operation of technological transport is being improved [19], [20]; however, all these measures do not solve the problem.

\subsection{Technology Improvement}

It is proposed to introduce a container technology of mined rock transportation in the opencast mining, which will allow increasing the opencast mining indicators in the area of saving energy resources and environment conservation at a totally new level.

It will include [21]:

- One-off rock fragmentation in the process of loading a container, which reduces energy consumption; 
- Delivery of mined rock by transportation of a container's assembly to the place of hoisting is performed at minimum horizontal road distances, which leads to reducing the required vehicle fleet, the rate of consumption of fuel, tires and emissions of harmful gases;

- The coefficient of dead load of a transport container (0.25-0.30) is significantly lower than the coefficient of a truck body $(0.70-0.80)$ or of railway transport $(0.80-0.82)$ therefore the unit cost of energy for transportation of the rock mass in a container reduces 1.4 times;

- The container hoisting hub is mobile, which allows moving to a new place during blasting operations or another bench in an open-pit mine with subsequent mining of the open-pit mines. Opportunities for regulation and maintenance of the optimum mining regime increase;

- A need for additional energy-intensive fragmentation of the mined rock is eliminated as opposed to the process schemes with the use of conveyer lifts;

- Container delivery of the overburden rock with the use of an open-pit mine hoist during liquidation of the open-pit mine will reduce the required land and form a compact height with minimum rock hoisting.

The key aspect of the proposed technology is in the fact that the entire equipment for container carriage is not difficult to produce and can be produced at mining enterprises. Walking mining excavators may be used as hoists.

In accordance with the basic process scheme of the open-pit mine hoisting containers are installed on benches of the open-pit mine for hoisting containers from the lower benches up (according to Fig. 1). On the intermediate platforms loaded and empty containers are cleared up. Following hoisting to benches, where the railway transport operates, containers are loaded directly into carriages.

One hoist serves two benches during the hoisting. The hoist is located at the platform of the lower bench beyond the possible caving area. The container is delivered by a container carrier to the bottom edge of the lower bench, the hoist moves the container to the upper bench platform from where a container is delivered to the next hoist through the interchange point.

The new technology may be applied within the existing combined transportation patterns, for example, within a motor-railway transportation pattern as an interagent - a hoisting-reloading point.

The container hoisting hub may become an alternative solution for a major problem of modern open-pit mines in tapping of new horizons, though it may be used at any mining stage in the open-pit mine.

Abandoning the hoisting of mined rock by motor transport provides an opportunity to increase the grade limit of ramps, as they will be used for traffic of only empty cars. A possible transition from the grades $8 \%$ to the grades $15 \%$ will reduce the area for positioning of ramps in the open-pit mine [22].

Efficiency of a new technology will express in reducing by means of cost savings of specific energy consumption for transportation of the mined rock compared to the most common technology with the use of motor-railway transport with reloading at the internal open-pit mine warehouses: for hoisting the mined rock by an electric drive hoist in containers with the minimum dead load coefficient; from reducing the coefficient of overburden removal by reducing the area of the reloading point, which organization in this case loses its meaning. 


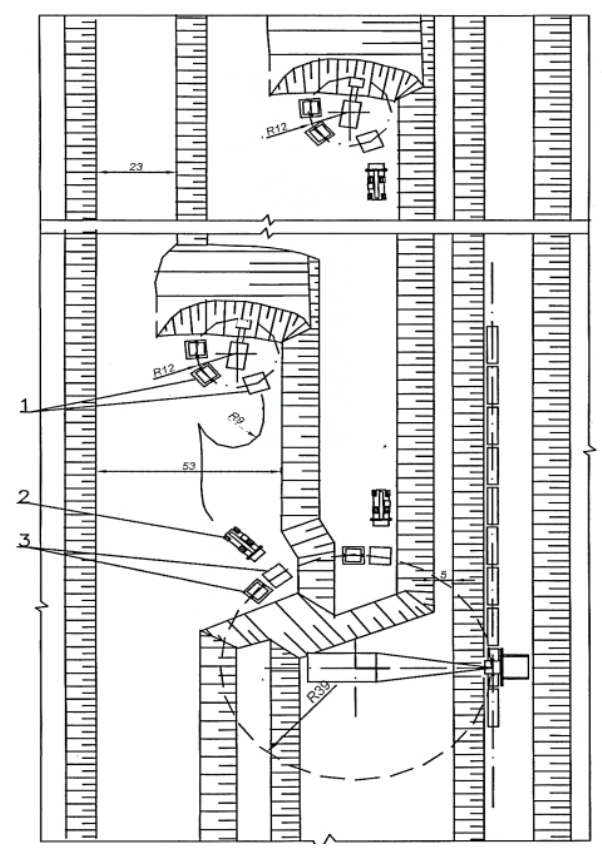

Fig. 1. Plan of energy-saving container technology in opencast mining: 1 - containers under loading; 2 - container carriers; 3 - containers on the platform at the hoist.

The hoist capacity is justified by required productivity of the open-pit mine. The productivity of the hoist $Q_{\text {year }}$, thous. t/year will be determined depending on the time of its operating cycle $T_{\mathrm{c}}$ according to the equitation [23]:

$$
Q_{\text {year }}=\frac{3600 \cdot T_{\mathrm{c}} \cdot K_{\mathrm{eu}} \cdot Q_{\mathrm{cont}} \cdot K_{\mathrm{cu}}}{T_{\text {cycle }}},
$$

where

$T_{\mathrm{c}} \quad$ Calendar annual fund of time, $T_{\mathrm{c}}=8760, \mathrm{~h}$;

$K_{\text {eu }} \quad$ Coefficient of equipment use, $K_{\text {eu }}=0.75$;

$Q_{\text {cont }} \quad$ Container capacity, t;

$K_{\mathrm{cu}} \quad$ Coefficient of the capacity use, $K_{\mathrm{cu}}=0.95$;

$T_{\text {cycle }} \quad$ Time of cycle, $\mathrm{s}$.

We shall assess the impact of the container's capacity complex on the productivity, accepting the time of cycle according to the passport speed of hoisting of a walking excavator $1 \mathrm{~m} / \mathrm{s}$ [24]. The time of hoisting to the height of $80 \mathrm{~m}$ will be $80 \mathrm{~s}$ and taking the coupling into account the total time of the hoist's cycle is $220 \mathrm{~s}$.

During movement of a dump truck, the ascent time to the height of $H=80 \mathrm{~m}$ under the grade of $i=80 \%$ and average speed $V=15 \mathrm{~km} / \mathrm{h}$ will be: $t=H /(1000 \cdot i \cdot V)=80 /$ $(0.08 \cdot 15 \cdot 1000)=0.067 \mathrm{~h}$.

Consequently, during movement of a dump truck, only the time of the truck ascent will be $240 \mathrm{~s}$.

The impact of the container capacity $(G)$ on the productivity of hoisting devices $(Q)$ is given in Fig. 2. 


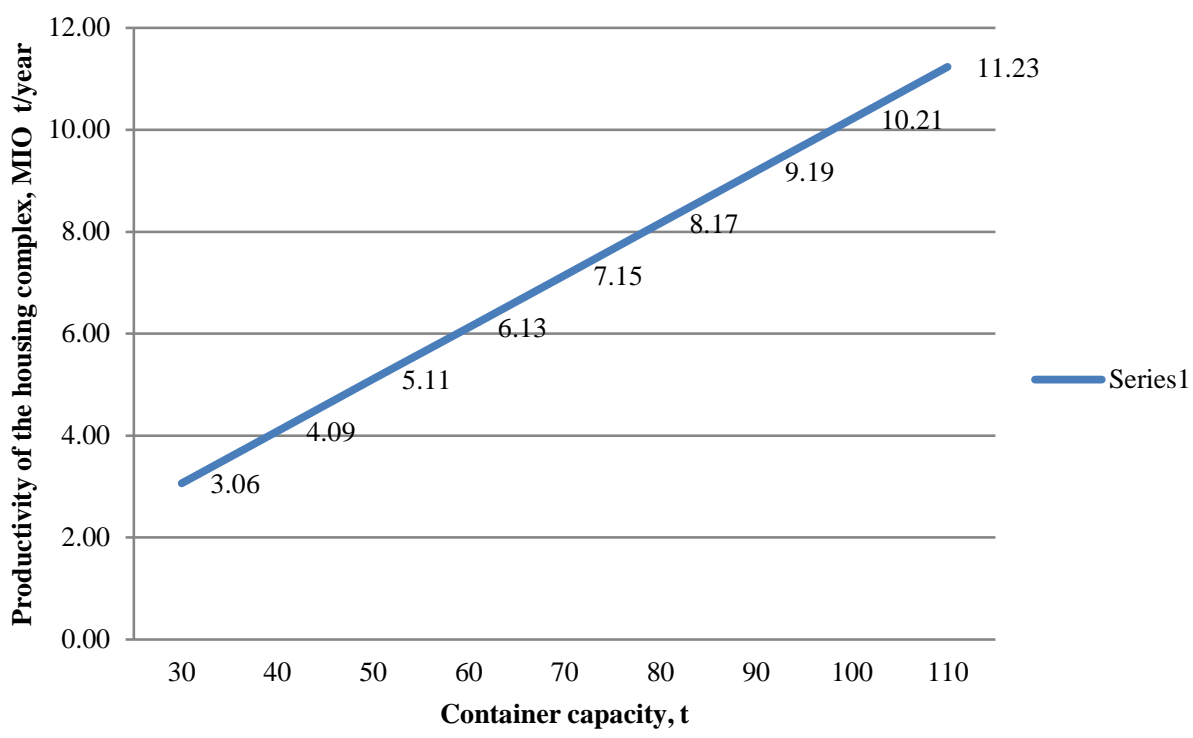

Fig. 2. Impact of the container capacity on the productivity of the hoisting complex.

Within analysis of the graph it can be seen that one complex of hoisting devices with containers with the carrying capacity of $80 \mathrm{t}$ may secure productivity around 9 million tons/year but if higher productivity is required, it is necessary to increase the number of hoisting complexes.

Within introduction of a container hoisting the concertation of harms in the atmosphere of the open-pit mine is determined according to the Eq. (1)-(4). The results of calculations are presented in Table 3 and Table 4.

TABle 3. Results of Calculations for Dust in AN OPEn-Pit Mine, EQ. 1-4

\begin{tabular}{llll}
\hline Type of equipment & $\boldsymbol{m}_{\mathbf{i}}, \mathbf{p c s}$. & $\boldsymbol{F}_{\mathbf{i}}, \mathbf{m g} / \mathbf{s}$ & $\boldsymbol{J}, \mathbf{m g} / \mathbf{s}$ \\
\hline Drilling rigs & 1 & 2600 & 458 \\
Excavators & 2 & 400 & 211 \\
Dump trucks & 4 & 12000 & 2112 \\
Bulldozers & 1 & 2000 & 352 \\
Hoists & 1 & 400 & 211 \\
\hline
\end{tabular}

TABLE 4. Results of CALCULATIONS FOR GAS IN AN OPEN-Pit Mine, EQ. 1-4

\begin{tabular}{|c|c|c|c|c|c|c|}
\hline Gas & MAC norm, \% & Type of equipment & $m_{\text {i, }}$ pcs. & $F_{\mathrm{i}}, \mathrm{mg} / \mathrm{s}$ & $J, \mathrm{mg} / \mathrm{s}$ & $\Sigma$ \\
\hline \multirow{2}{*}{$\mathrm{CO}$} & \multirow{2}{*}{20} & Dump trucks & 4 & 1150 & 20 & \multirow{2}{*}{196} \\
\hline & & Bulldozers & 1 & 1000 & 176 & \\
\hline \multirow{2}{*}{$\mathbf{N}_{2} \mathbf{O}_{5}$} & \multirow{2}{*}{5} & Dump trucks & 4 & 1305 & 23 & \multirow{2}{*}{217} \\
\hline & & Bulldozers & 1 & 1100 & 194 & \\
\hline \multirow{2}{*}{ Acrolein } & \multirow{2}{*}{0.7} & Dump trucks & 4 & 6 & 0.104 & \multirow{2}{*}{0.984} \\
\hline & & Bulldozers & 1 & 5 & 0.88 & \\
\hline
\end{tabular}


The initial dust concentration in the atmosphere of an open-pit mine $\left(C, \mathrm{mg} / \mathrm{m}^{3}\right)$ is determined according to the equitation:

$$
C=\frac{3344}{12360 \cdot 0.8}=0.33 \mathrm{mg} / \mathrm{m}^{3} .
$$

The initial concentration of $\mathrm{CO}$ gas:

$$
C=\frac{196}{12360 \cdot 0.8}=0.02 \mathrm{mg} / \mathrm{m}^{3} .
$$

The initial concentration of $\mathrm{N}_{2} \mathrm{O}_{5}$ gas:

$$
C=\frac{217}{12360 \cdot 0.8}=0.022 \mathrm{mg} / \mathrm{m}^{3} \text {. }
$$

The initial concentration of acrolein gas:

$$
C=\frac{0,984}{12360 \cdot 0.8}=0.00009 \mathrm{mg} / \mathrm{m}^{3} \text {. }
$$

Introduction of this technology reduces concentration of dust almost by $50 \%$ and for gas on average by $20 \%$ (Fig. 3).

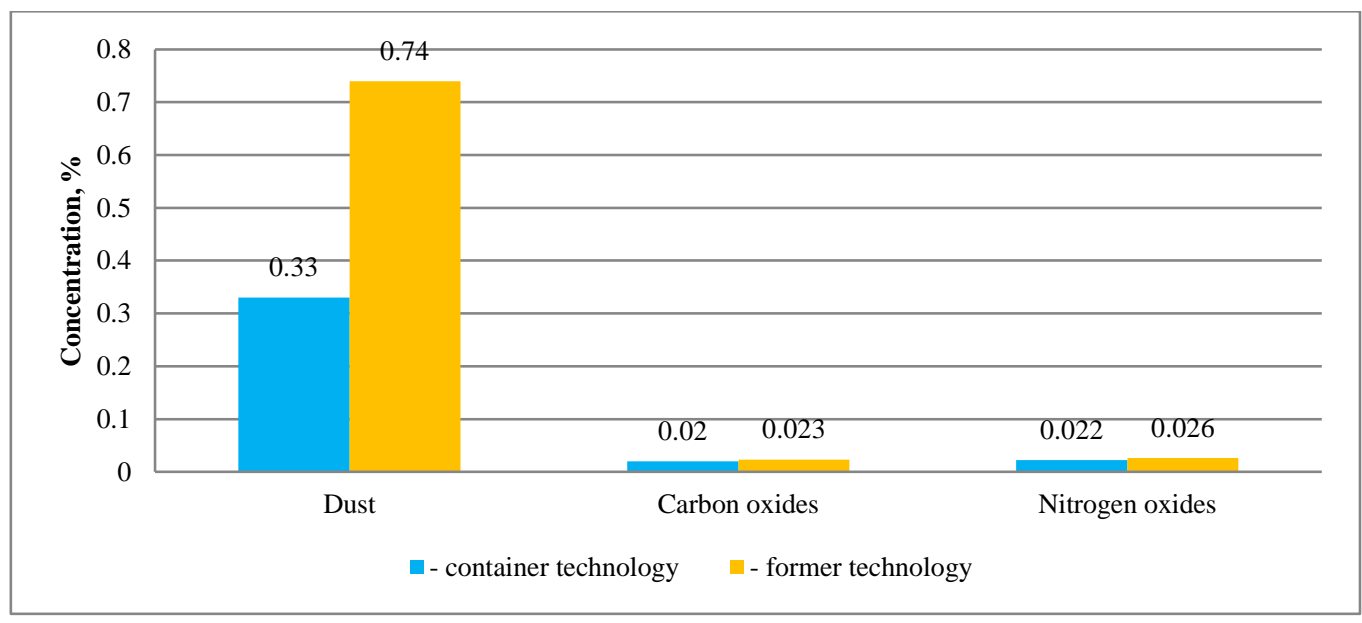

Fig. 3. Reduction of harms in the atmosphere of an open-pit mine as a result of introduction of a container technology.

\section{Results}

The efficiency of container hoisting in the container technology of the opencast mining is in the reduction of energy and economic losses due to down time of vehicles under loading and in productivity increase of an excavator. The cycle path of a container carrier does not include down time during loading as opposed to dump trucks and railway trains. 
The process scheme with the use of hoisting devices of the open-pit mine is sufficiently reliable, flexible and diverse. This allows gradual increasing of the height of hoist, positioning the systems of hoisting devices on the open pit benches, distributing or combining the cargo traffic according to the types of mined rock.

In this case the means of increasing the efficiency of the transport system will be application of container equipment in the motor transport working area based on the increase of capacity of container carriers with the help of traction engines with an electric drive. If the hoisting height by one hoisting mechanism is insufficient, two- or three-stage hoisting is possible. This will allow reducing or excluding the container conveyance by container carriers, which deliver loaded containers from excavators to the hoisting locations. In the container technology the mined rock according to Fig. 1 is loaded to containers by excavators. Twothree containers are set up in the area of excavator's operations. The exchange of loaded containers to empty ones is performed by automatic loaders - container carriers. They deliver loaded containers to short distances on the container platform in the area of works of the next hoisting device. Container carriers also perform descent of empty containers into the openpit mine [25].

In the container technology within the opencast mining the mined rock is loaded by face shovels into containers, which are delivered by hoisting-transport vehicles to the reloading point. Then containers are hoisted to surface by hoists and are delivered to concentrating factories or mine dumps by container carriers. There, a hoist carries out its automatic reloading by gripping it (Fig. 4).

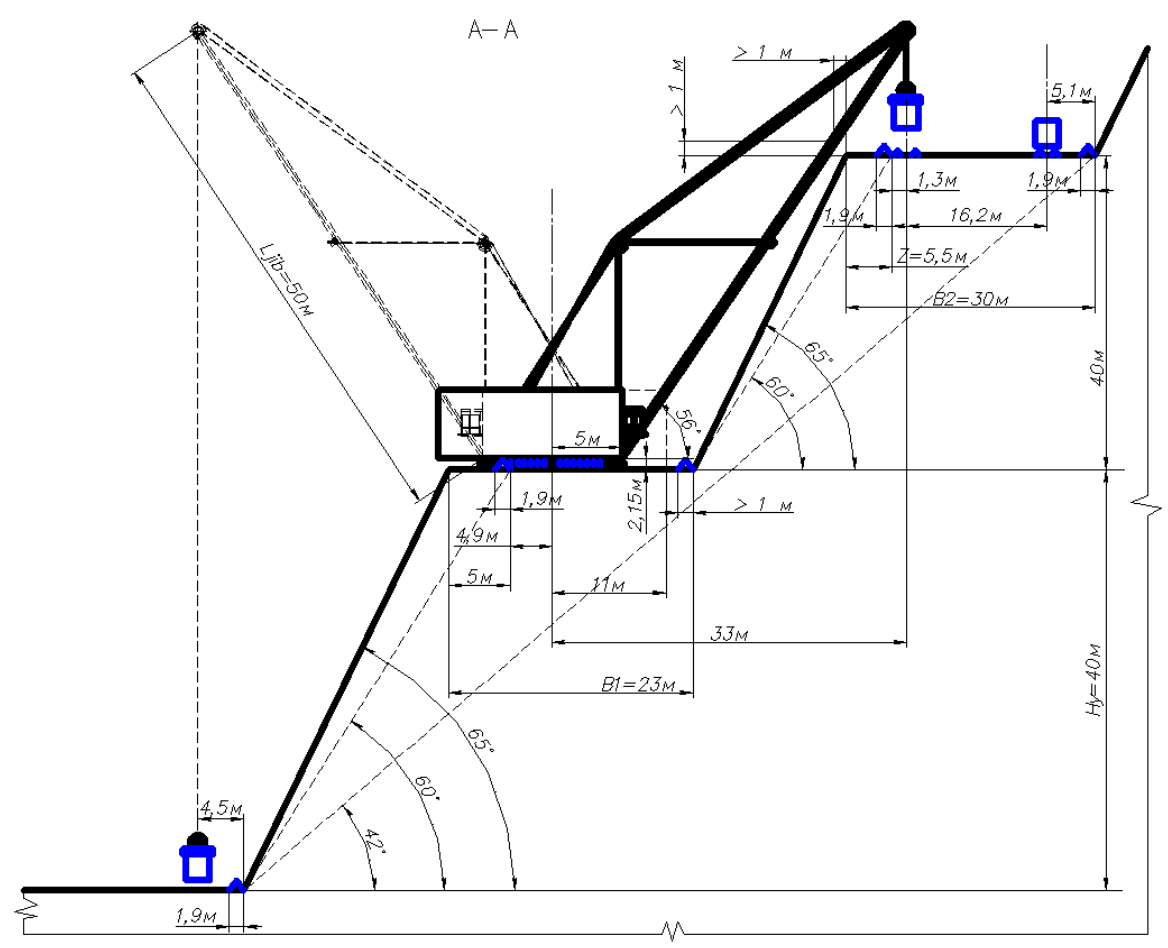

Fig. 4. Passport of setting up a hoist on a bench. 
The container requirements are the following: small dead weight; increased functional reliability; simplicity of construction; a possibility of transportation of coarse freights and full automatization of operation. As a result of work on the subject a container conforming to all the above requirements was designed. Operation of the developed equipment for transportation of the mined rock takes place as follows. The container represents a welded box-type structure. The external view of the designed container is shown in Fig. 5 [24].

Container's bottom is hinged. Its opening is mechanical by means of a lever system (Fig. 6). The bottom is fixed on three brackets. The operational scheme of the bottom opening levers is presented in Fig. 2. Within loading the container is set up on the ground on four legs 1, they lift and move the lever 3, which through the bracket 2 keeps bottoms closed. The container is lifted by side stops located on the side walls.

At the same time the stops of the hauling device go through the ears 5 and keep the container closed. When unloading is required, the stops going into the ears 5 come out and rocks by its own weight are emptied from the container. Closing of the bottom takes place when the container is put on the ground which makes legs 1 moving up.

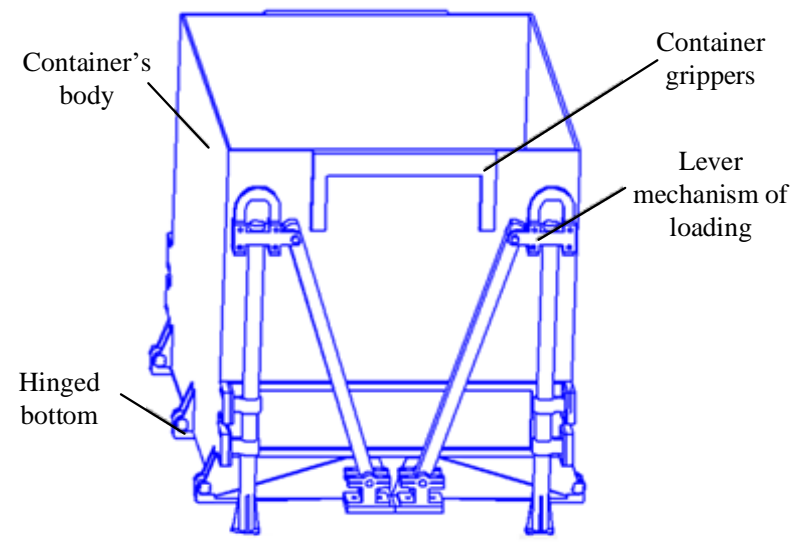

Fig. 5. Container pattern.
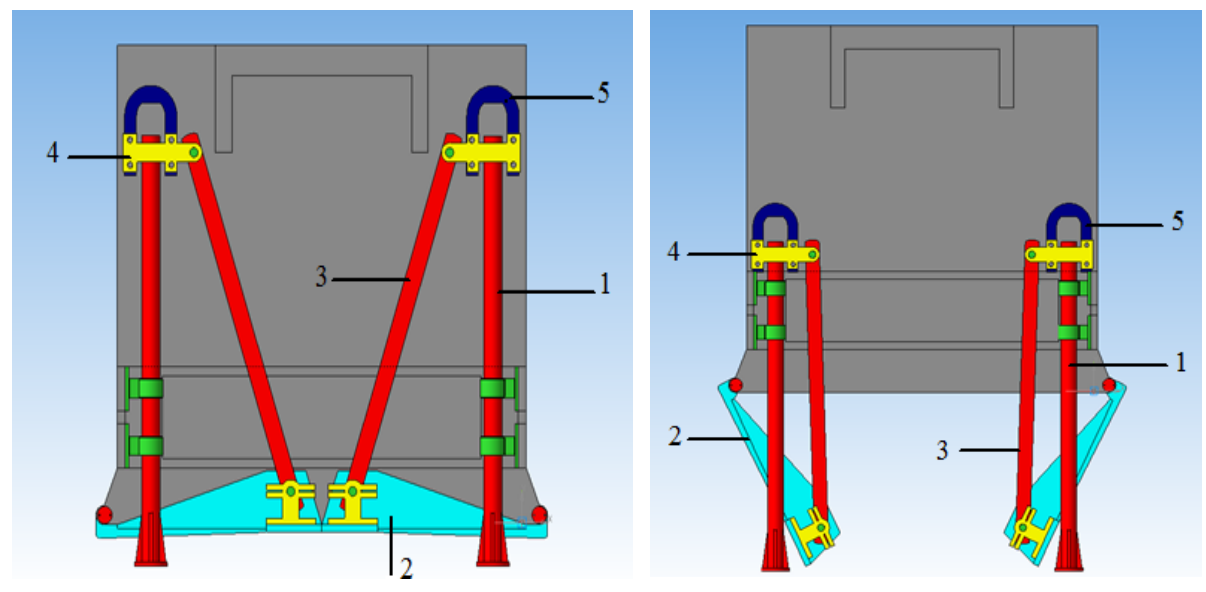

Fig. 6. Operational scheme of container levers during loading and unloading. 
All components and units of the container are calculated based on durability with the help of computer modelling methods.

\section{DISCUSSION}

Calculations of the use of container technologies in deep open-pit mines showed that compared to traditional options of transportation of the mined rock by motor transport or combined motor-railway transport, the energy efficiency of the new technology is obvious and the level of its advantage increases with the increasing hoisting height of the mined rock.

The amount of equipment for the two technologies with the use of motor and container transport at different depth of the open-pit mine is provided in Table 5.

TABle 5. OPERATIONAL FlEET OF EQUiPMENT AT DifFERENT DEPTH OF AN OPEN-Pit Mine

\begin{tabular}{lllllllll}
\hline \multirow{2}{*}{ Name of equipment } & \multicolumn{7}{c}{ Depth of an open-pit mine, m } \\
& 40 & 80 & 120 & 160 & 200 & 240 & 280 & 320 \\
\hline Technology with the use of motor transport & 3 & 3 & 3 & 3 & 3 & 3 & 3 & 3 \\
\hline Excavators, pcs. & 4 & 6 & 8 & 10 & 10 & 12 & 14 & 16 \\
Dump trucks, pcs. & & & & & & & & \\
\hline Container technology & 1 & 1 & 1 & 1 & 1 & 1 & 1 & 1 \\
\hline Excavators, pcs. & 1 & 1 & 2 & 2 & 3 & 3 & 4 & 4 \\
Hoists, pcs. & 6 & 7 & 12 & 13 & 16 & 17 & 21 & 22 \\
\hline Containers, pcs. & 0 & 0 & 2 & 2 & 4 & 4 & 6 & 6 \\
Rail-mounted trams, pcs. & 0 & 0 & 2 & 2 & 4 & 4 & 6 & 6 \\
Winch, pcs. & 3 & 3 & 3 & 3 & 3 & 3 & 3 & 3 \\
Container carrier, pcs. & 0 & 0 & 200 & 200 & 400 & 400 & 600 & 600 \\
Length of railway track, $\mathbf{m}$ & & & & & & & & \\
\hline
\end{tabular}

Number of face shovels in the motor transport technology will be 2, in the container technology -1 . Transportation of containers to the reloading point is performed by three container carriers. Each $80 \mathrm{~m}$ the number of hoists increases by one. In the motor transport technology, a reloading warehouse is required where another excavator will operate.

Total costs $T C$ of a new transportation pattern are determined according [27]-[32]:

$$
T C=C+E_{n} \cdot K
$$

where

C Operating costs, tKZT;

$K \quad$ Capital costs, tKZT;

$E_{\mathrm{n}} \quad$ Normative coefficient of efficiency of capital investment, $E_{\mathrm{n}}=0.12$.

Calculation of the total costs depending of the open-pit mine depth is provided in Table 6 .

The graph of growth of the economic efficiency of the container technology depending on the depth of an open-pit mine is presented in Fig. 7. 
TABle 6. CAlculation of Total Costs of A New Transportation PATtern

\begin{tabular}{lllllll}
\hline $\begin{array}{l}\text { Indicator } \\
\text { /depth, m }\end{array}$ & $\begin{array}{l}\text { Capital } \\
\text { costs, } \\
\text { MIO } \\
\text { KZT }\end{array}$ & $\begin{array}{l}\text { Operating costs } \\
\text { in the previous } \\
\text { technology, } \\
\text { MIO KZT }\end{array}$ & $\begin{array}{l}\text { Operating costs } \\
\text { in the new } \\
\text { technology, } \\
\text { MIO KZT }\end{array}$ & $\begin{array}{l}\text { Amount of } \\
\text { operating } \\
\text { costs' savings, } \\
\text { MIO KZT }\end{array}$ & $\begin{array}{l}\text { Economic } \\
\text { effect, MIO } \\
\text { KZT }\end{array}$ & $\begin{array}{l}\text { Economic } \\
\text { effect, thous. } \\
\text { USD* }\end{array}$ \\
\hline 40 & 791.6 & 1554.8 & 1056.7 & -498.1 & 371.4 & 1149.88 \\
80 & 791.6 & 1977.5 & 1062.6 & -914.9 & 788.2 & 2440.3 \\
120 & 894.4 & 2398.6 & 1345.3 & -1053.2 & 910.1 & 2817.78 \\
160 & 894.4 & 2804.3 & 1351.2 & -1453.1 & 1310.04 & 4055.84 \\
200 & 997.2 & 2818.9 & 1622.2 & -1196.7 & 1337.15 & 4318.52 \\
240 & 997.2 & 3208.5 & 1628.1 & -1580.4 & 1420.9 & 4399.06 \\
280 & 1099.9 & 3627.3 & 1905.0 & -1722.3 & 1546.36 & 4787.5 \\
320 & 1099.9 & 4043.0 & 1910.8 & -2132.2 & 1956.25 & 6056.5 \\
\hline
\end{tabular}

*Exchange rate is assumed as $323 \mathrm{KZT}$ per 1 USD.

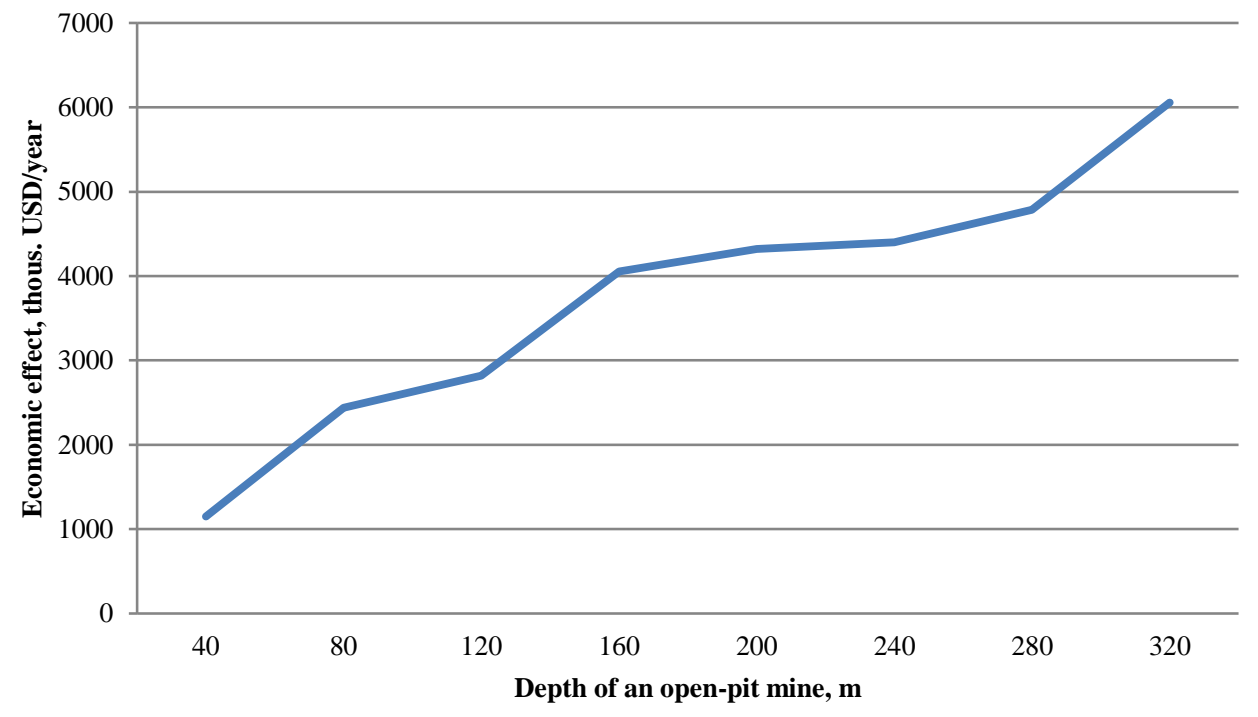

Fig. 7. Dependence of the economic efficiency of introduction of the container technology on the depth of an open-pit mine.

Having analysed the graph in Fig. 7, it can be concluded that the economic efficiency from introduction of a container hoisting in the open-pit mine increases with the growing depth of mining. It happens due to the reducing operating costs, such as diesel fuel consumption, amortized values and decreasing costs for equipment repairs and reducing the down time of the equipment due to environmental damages.

\section{Conclusions}

The container technology allows solving the entire set of objectives of the principal technological processes of the opencast mining - from the extracting of rock in the front to 
loading into vehicles at the reloading warehouse. The use of exchangeable containers in the fronts will significantly change the organizational principles of the excavation-transport hubs, will increase their productivity and a coefficient of the use of excavators within principal operations. Replacement of the obsolete extraction-and-loading equipment with the advanced one and increase of the transport provision of the fronts will increase the level of used area of mining and productive capacity of the open-pit mine.

The major advantage of the container technology is an automation outlook of a range of operations of the transport process in the open-pit mine and on the daylight area. The performed assessment of the economic indicators of the container technology shows its economic advantages over the current methods of mined rock delivery. In the process of technical and economic justification of the introduction of the container technology a detailed comparison of the two technologies of deep horizon development was carried out - with the help of the motor transport and containers. As a result, at all depths of the open-pit mine the economic effect within the range from 1 to 6 million USD a year was obtained.

\section{REFERENCES}

[1] Yudin A. V. Theory and technical solutions of transport and cargo handling systems in quarries. Scientific monograph. Ekaterinburg: USMU, 2011. (in Russian)

[2] Rodzkin A., Kundas S., Charnenak Y., Khroustalev B., Wichtmann W. The Assessment of Cost of Biomass from PostMining Peaty Lands for Pellet Fabrication, Environmental and Climate Technologies 2018:22:(1):118-131. https://doi.org/10.2478/rtuect-2018-0008

[3] Beresnevich P. V., Mikhajlov V. A., Filatov S. S. Aerology of the open pit. Spravochnik. Moscow: Nedra, 1990. (in Russian)

[4] Pevzner M. E. Mountain ecology. Moscow: Moscow State University, 2003. (in Russian)

[5] Kittipongvises S. Feasibility of Applying Clean Development Mechanism and GHGs Emission Reductions in the Gold Mining Industry: A Case of Thailand. Environmental and Climate Technologies 2015:15(1):34-47. https://doi.org/10.1515/rtuect-2015-0004

[6] Sheshko E. E. Mining transportation machines and equipment for open pit mining. Moscow: MISIS, 2006. (in Russian)

[7] Kolikov K. S., Zakharova A. A., Bitugin A. S., Golovko I. V., Musina V. R. Gornopromishlennaja ekologija. Praktikum. Gornyi Zhurnal 2019. (in Russian)

[8] Pevzner M. E. Gornaya ekologija. Moscow: MGTU, 2003. (in Russian)

[9] Pevzner M. E., Malishev A. A., Melnikov A. D., Ushakov V. P. Gornoe delo I okhrana (Mining and environmental protection). Moscow: MGTU, 2001. (in Russian)

[10] Shischich I. U. Geotechnology and environmental protection of underground space and the environment. Moscow: Gornaya kniga, MGTU, 2010. (in Russian)

[11] Astakhov A. S. Ecological safety and efficiency of environmental management, Moscow: Gornaya kniga, MGTU, 2009. (in Russian)

[12] Kretser H. E., Beckmann J. P., Berger J. A Retrospective Assessment of a Failed Collaborative Process in Conservation. Environmental Management 2018:62(3):415-428. https://doi.org/10.1007/s00267-018-1045-2

[13] Yakovlev V. L., Tarasov P. I., Zhuravlev A. G. New specialized types of transport for mining. Monograph. Ekaterinburg: Rossiiskaya akademiya nauk, Ural'skoe otdelenie, Institut gornogo dela, 2011. (in Russian)

[14] Cheban A. Yu. Method and equipment for opencast mining of small steeply dipping deposits. Vestnik of Nosov Magnitogorsk State Technical University 2017:15(3):18-23. https://doi.org/10.18503/1995-2732-2017-15-3-18-23

[15] Kadnikova O., Altynbayeva G., Kuzmin S., Khabdullina Z. Ecological Feasibility of Applying Technology in Recycling Garment and Knitwear Production. Environmental and Climate Technologies 2019:23(2):291-309. https://doi.org/10.2478/rtuect-2019-0069

[16] Diaz F., Cilinskis E. Use of Multi-Criteria TOPSIS Analysis to Define a Decarbonization Path in Colombia. Environmental and Climate Technologies 2019:23(3):110-128. https://doi.org/10.2478/rtuect-2019-0083

[17] Potapov M. G., Komrakov A. N. Ekologicheskaja ocenka tehnologicheskih shem otkritih gornih rabot. Gornyi Zhurnal 2003:3:81-86. (in Russian)

[18] Kubule A., Komisarova T., Blumberga D. Optimization Methodology for Complete Use of Bio-resources. Energy Procedia 2017:113:28-34. https://doi.org/10.1016/j.egypro.2017.04.009)

[19] Vuyeykova O., Sladkowski A., Stolpovskikh I., Akhmetov M. Rationalization of road transport park for the carriage of mining rocks in the open mines. Transport Problems 2016:11(1):79-85. https://doi.org/10.20858/tp.2016.11.1.8 
[20] Chanda E. K., Gardiner S. A. Comparative study of truck cycle time prediction methods in open pit mining. Engineering Construction and Architectural Management 2010:17(5):446-460. https://doi.org/10.1108/09699981011074556

[21] Bitimbaev M. Zh., Zhunusov T. T., Maulyanbaev T. I., Kuzmin S. L. Designing equipment for containerized rock delivery technology in open pit mining. CUMR 2012:2:3-7. (in Russian)

[22] Bitimbaev M. Zh., Kuzmin S. L., Maulyanbaev T. I. Osadchyi V. I., Oryn-gozhin E. S. The use of container-type transportation system in open pit mining: Monograph. Almaty: ALESHAN, 2015. (in Russian)

[23] Rzevsky V. V. Open pit mining. Technology and overall mechanization. Moscow: LIBROKOM Publishing House, 2014. (in Russian)

[24] Trubetskoy K. N., Potapov M. G., Vinnitsky K. E., et al. Open Pot Mining Manual. Moscow: Gornoe byuro, 1994. (in Russian)

[25] Khabdullin A., Khabdullina Z., Khabdullina G., Lauka D., Blumberga D. Demand response analysis methodology in district heating system. Energy Procedia 2017:128:539-543. https://doi.org/10.1016/j.egypro.2017.09.004

[26] Kadnikova O., Altynbayeva G., Aidarkhanov A., et al. Improving the technology of processing sewing and knitwear production waste. Energy Procedia 2016:113:488-493. https://doi.org/10.1016/j.egypro.2017.04.047

[27] Khabdullin A., Khabdullin A., Khabdullina Z., Khabdullina G. Mathematical model of synchronous motors for static characteristics power loss. Energy Procedia 2015:95:487-490. https://doi.org/10.1016/j.egypro.2016.09.073

[28] Cimdina G., Timma L., Veidenbergs I., Blumberga D. Methodologies used for scaling-up from a single energy production unit to state energy sector. Environmental and Climate Technologies 2015:15:5-21. https://doi.org/10.1515/rtuect-2015-0002

[29] Bassi A. M. Moving towards integrated policy formulation and evaluation: The green economy model. Environmental and Climate Technologies 2015:16:5-19. https://doi.org/10.1515/rtuect-2015-0009

[30] Slisane D., Blumberga D. Assessment of roadside particulate emission mitigation possibilities. Environmental and Climate Technologies 2013:12:4-9. https://doi.org/10.2478/rtuect-2013-0009

[31] Robinson K. F., Fuller A. K., Stedman R. C., Siemer W. F., Decker D. J. Integration of social and ecological sciences for natural resource decision making: challenges and opportunities. Environmental Management 2019:63(5):565-573 https://doi.org/10.1007/s00267-019-01141-2

[32] Baird J., Schultz L., Plummer R., Armitage D., Bodin Ö. Emergence of Collaborative Environmental Governance: What are the Causal Mechanisms? Environmental Management 2019:63(1):16-31. https://doi.org/10.1007/s00267018-1105-7
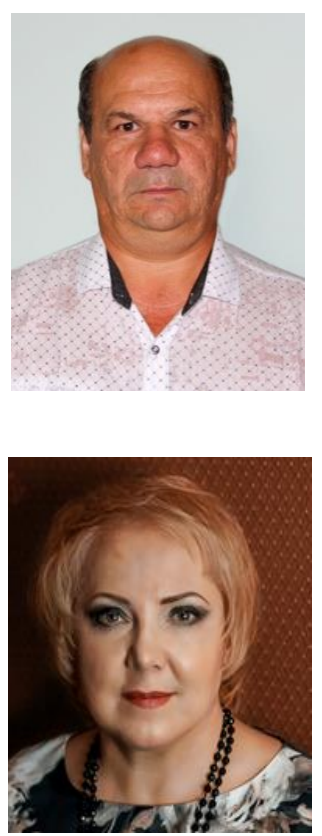

Sergey Kuzmin, candidate of engineering sciences, dean of the Mining and Metallurgical faculty at the Rudny Industrial Institute, Kazakhstan. Candidate thesis was devoted to the development of parameters of self-propelled chassis of auxiliary equipment for conditions of underground mines and protected at the Kazakh National Technical University (2010). The main direction of research is ecological safety during mining. He participates in various local projects related to the problems of rational subsoil use in the iron ore basin; he is the author of more than 90 publications and 10 books.

E-mail: decan_2008@mail.ru

ORCID iD: https://orcid.org/0000-0003-1934-9408

Olga Kadnikova, candidate of engineering sciences, dean of the Faculty of Economics and Construction, at the Rudny Industrial Institute, Kazakhstan. She defended her thesis on the specialty "Geoecology" at the Taraz State University (2010). The main area of research is the development of methods and devices for the processing of waste production. She was the head of the scientific research on the topic "Development of methods and devices for processing waste of sewing and knitting production" on the priority "rational use of natural resources, processing of raw materials and products", financed by the Ministry of Education of the Republic of Kazakhstan, took part in various local projects related to the processing of waste production, is the author of more than 90 publications and 5 books.

E-mail: kadnikovaolga@mail.ru

ORCID iD: https://orcid.org/0000-0001-9042-5296 

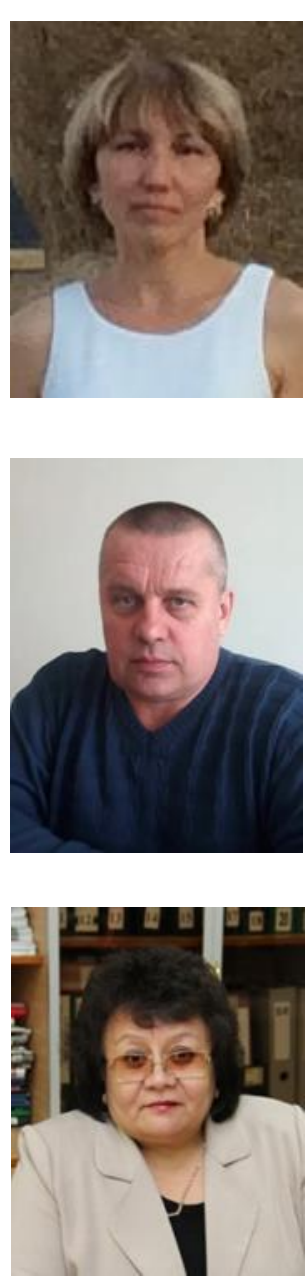

E-mail: Habdullina@ rii.kz ORCID iD: https://orcid.org/0000-0002-3310-2818
Gulnara Altynbayeva, candidate of engineering sciences, associate professor at the Rudny Industrial Institute, Kazakhstan. Candidate dissertation work was devoted to the problem of introducing waste-free technology into production, protected at the Almaty Technological University (2003). Since 2009, Gulnara Altynbaeva is an assistant professor of the department of the Rudny Industrial Institute. The main direction of research is the recycling of production waste. She participated in scientific research on the topic "Development of methods and devices for processing waste of sewing and knitting production" on the priority "rational use of natural resources, processing of raw materials and products", financed by the Ministry of Education of the Republic of Kazakhstan, various local projects related to the processing of waste of production, is the author of more than 60 publications and 5 books. E-mail: altynbaeva_g@mail.ru ORCID iD: https://orcid.org/0000-0002-7986-8325

Andrei Turbit, senior lecturer at the Rudny Industrial Institute, Kazakhstan. He is engaged in the development of energy-saving technologies for the transportation of mining masses. $\mathrm{He}$ participates in scientific research on the topic "Improvement of Open Mining Technology by creating temporary Internal Blades" according to the priority "Rational use of Natural Resources, Processing of raw Materials and Products", financed by the Ministry of Education of the Republic of Kazakhstan, is the author of more than 25 publications.

E-mail: tyrbit_andron@mail.ru

ORCID iD: https://orcid.org/0000-0002-5432-5463

Zauresh Khabdullina, candidate of engineering sciences, associate professor of the Republic of Kazakhstan, professor of the Rudny Industrial Institute, head of the department of "Electric Power and Heat Energy", Kazakhstan. She defended her thesis on the specialty "Electrical complexes and systems, including their management and regulation" at the Moscow Energy University (1993). The main direction of research is accounting, control of electric consumption, energy saving and energy efficiency. It participated in several research projects of the republican levels related to the technology of integrated energy saving based on the rational use of renewable energy sources (2009); with energy saving in industry and in housing and communal services based on the introduction of renewable energy sources (2012); with the development of energy-saving methods for optimizing the modes of operation of electricity systems in order to minimize power and load losses (2015-2017); author of more than 100 publications and 15 books. 